\title{
Питання психології
}

УДК 378:355 (477)

DOI: 10. 33099/2617-6858-21-59-1-209-219

Чайковський $\boldsymbol{A}$. C. доктор історичних наук, професор, Центр воєнно-стратегічних досліджень Наџіональний університет оборони України імені Івана Черняховського Поздишев С. О. кандидат психологічних наук, Національний університет оборони Украӥни імені Івана Черняховського https://orcid.org/0000-0001-7225-709x

Мацько О. Й. кандидат військових наук, професор, Національний університет оборони України імені Івана Черняховського https://orcid.org/0000-0003-3415-3358

\section{ПАТРІОТИЧНЕ ВИХОВАННЯ В СИСТЕМІ ВИЩОЇ ВІЙСЬКОВОЇ ОСВІТИ ЯК СКЛАДОВА ЗАБЕЗПЕЧЕННЯ НАЦІОНАЛЬНОЇ БЕЗПЕКИ УКРАЇНИ}

У статті розглянуто роль та місие патріотичного виховання у системі забезпечення національної безпеки України. Проаналізовано різні наукові підходи щчодо визначення поняття патріотизму. Виявлені концептуальні засади, складові, напрями та проблеми патріотичного виховання в національній системі вищзої військової освіти, розкриті його вплив на ефективність забезпечення національної безпеки України. Визначені суб 'єкти й об 'єкти патріотичного виховання у Збройних Силах Украӥни.

Ключові слова: патріотичне виховання; вищчй військовий навчальний заклад; молодь; курсант;військовослужбовещь; Збройні Сили Украӥни.

Вступ.

На нинішньому етапі розвитку українського суспільства, коли країна в екстремальних умовах демонструє ознаки системної кризи усіх галузей суспільнодержавної діяльності, актуалізується проблема забезпечення національної безпеки України. Це обумовлено як гібридною агресією проти України 3 боку Російської Федерації, так i внутрішньополітичними проблемами національного істеблішменту, які виявили низку системних проблем у забезпеченні національної безпеки.

Специфіка бойових дій в зоні Перської затоки, Югославії та Україні засвідчують, що воєнний успіх можливий за двох умов: 1) оснащення збройних сил найсучаснішою зброєю і бойовою технікою; 2) забезпечення армії професійно підготовленими i патріотично налаштованими військовими кадрами.

На жаль, військово-політичні реалії 2014-2016 років (анексія Росією Криму, окупація частини Донецької та Луганської області) свідчать, що стан справ в Збройних Силах України не відповідав сучасним вимогам. На початковому етапі російської агресії мали місце непоодинокі випадки неготовності певної частини особового складу силових структур до виконання своїх обов'язків щодо збройного захисту національного суверенітету та територіальної цілісності України. Зокрема, окремі військовослужбовці перейшли на бік агресора, однією 3 причин чого стала відсутність у них належної особистої мотивації щодо виконання службових i громадянських обов'язків, зокрема, брак патріотизму. Такі явища свідчать про наявність глибоких проблем у двох вищеназваних напрямах забезпечення національної безпеки.

Відтак, актуальним $є$ осмислення i практичне розв'язання проблем національнопатріотичного виховання майбутньої військової інтелігенції в системі вищої військової освіти, яке набуває значення системоутворюючого чинника розбудови Збройних Сил України, оскільки відкриває шлях формування нових основ політичної культури, громадянської свідомості і поведінки військовослужбовців та $\epsilon$ складовою забезпечення національної безпеки України на сучасному етапі.

Мета статті. У вищих військових навчальних закладах Міністерства оборони України (далі - ВВНЗ) та військових навчальних підрозділах закладів вищої освіти (далі - ВНП ЗВО) патріотичне виховання має чітку цільову настанову - готувати до захисту Батьківщини, i виступає невід'ємною складовою системи забезпечення національної безпеки України. У сучасних умовах актуальним завданням $\epsilon$ теоретичне переосмислення підвалин патріотизму, формування нових підходів до національнопатріотичного виховання молодого покоління в цілому, і у системі вищої 


\section{Питання психології}

військової освіти зокрема. Актуальність проблеми та стан іï наукової розробки обумовлюють мету нашої наукової розвідки - проаналізувати концептуальні засади, складові, напрями та проблеми патріотичного виховання в національній системі вищої військової освіти та розкрити його вплив на ефективність забезпечення національної безпеки України.

Теоретичне підгрунтя. Науковий інтерес до проблем патріотизму спостерігався упродовж всієї історії розвитку суспільно-політичної думки. Абстрактнотеоретичний підхід до патріотизму як суспільного явища простежується в роботах М. Вебера, Е. Дюркгема, Т. Парсонаса.

Грунтовний аналіз патріотизму здійснено в роботах П. Бурдьє, У. Бека, І.Валлерстайна, П. Штомпки, 3. Баумана, Ю. Хабермаса. Проблема патріотизму порушувалася також у роботах громадських, політичних і культурних діячів України - В. Винниченка, О. Духновича, М. Грушевського, А. Макаренка, Г. Сковороди, В. Сухомлинського, К. Ушинського, I.Франка, Т. Шевченка та ін. Проблеми становлення, функціонування i розвитку духовного потенціалу Збройних Сил України, формування системи виховної роботи серед особового складу та модернізації iï змісту досліджено у військово-теоретичних працях соціальнофілософського рівня В. Абрамова, В. Алещенка, В. Ананьїна, В. Баранівського, В. Ваврика, О. Загорка, В. Здіорука, В. Корженка, I. Муковецького, О. Разумцева, Ю. Решетнікова, Ю. Руденка, В. Сергійчука, В. Смолянкжа, Г. Темки, М. Цюрупи, В. Ягупова.

Аспекти військової освіти та військовопедагогічної діяльності відображені в працях А. Барабанщікова, Г. Васяновича, М. Варія, М. Коваля, М. Козяра, О. Панфілова, I. Севрук, Г. Фініна, В. Ягупова та інших дослідників.

Теоретичні та методичні аспекти патріотичного виховання серед військовослужбовців знайшли своє висвітлення в роботах українських військових дослідників В. Алещенка, А. Афанасьєва, В. Баранівського, В. Грицюка, В. Дзюби, Ю. Красильника, Г. Лісовського, М. Нещадима, Л. Олійника, Р. Суворова, Г. Темка, Г. Яблонської, В. Ягупова та ін.

У роботах українських військових дослідників висвітлено сучасний стан патріотичного військовослужбовців Збройних Сил, здійснено аналіз змісту i форм виховної роботи в системі вищої військової освіти, розроблено новітні технології національнопатріотичного виховання майбутніх військових фахівців різних рівнів, відомств і видів військ Збройних Сил України в контексті специфіки їх професійної діяльності (офіцерів-резервістів, військовослужбовців, строковиків, прикордонників, правоохоронців тощо).

Методи дослідження. Для вирішення мети були використані загальнотеоретичні методи: аналіз, синтез положень, що містяться у педагогічній, психологічній та дотичній літературі 3 проблеми, що вивчається, порівняння, узагальнення, інтерпретація та систематизація теоретичних та емпіричних досліджень.

Результати і обговорення. Останнім часом ми стали свідками девальвації духовних цінностей, поширення у суспільній свідомості апатії, егоїзму, індивідуалізму, цинізму, невмотивованої агресивності, зниження на державному рівні відповідальності за вирішення внутрішніх проблем ЗС України. В умовах зовнішньої збройної агресії та порушення територіальної цілісності держави нового звучання набувають такі історично сформовані цінності як «Батьківщина», «Патріотизм», «Честь», «Гідність», «Самовідданість», «Жертовність» та ін. Аксіологічний вимір проблеми полягає у рівні сприйняття громадянами України в цілому і майбутніми офіцерами зокрема таких базових цінностей як цілісність України, іï незалежність, державний суверенітет i непорушність кордонів, вітчизняна історія, українська мова і культура, історія і мова народів України, європейські ідеали свободи, справедливості, принципи правової держави та народовладдя, безумовне виконання законів, статутів, повага військових традицій, патріотизм, відвага, мужність, офіцерська честь, які виступають базовими цінностями, ядром яких $\epsilon$ конституційні основи суспільного ладу. Засвоєння цих цінностей майбутніми офіщерами в системі вищої військової освіти, усвідомлення їх ролі і місця в забезпечені надійного захисту Батьківщини $\epsilon$, серед іншого, запорукою національної безпеки.

Результат патріотичного виховання знаходить своє вираження в спектрі та рівні моральних, політичних, правових і бойових якостей, сформованих у конкретного військовослужбовця [4]. Нині не втрачає актуальності думка С. Крилова, який 


\section{Питання психології}

зазначав, що «формування сталого фундаменту ціннісних категорій і життєвих «маяків» для особистості - це на сьогодні єдиний шлях подолання кризи у системі військово-патріотичного виховання молоді» [7]. Йдеться про створення цілісної системи виховання військовослужбовців нового типу, відданих справі і своій державі, патріотично налаштованих, наділених високими морально - бойовими якостями, ініціативних, цілеспрямованих, готових брати на себе відповідальність за захист Батьківщини.

32014 року сама ідея формування i розвитку особистості громадянина, патріота, захисника Вітчизни зазнає суттєвих змін $\mathrm{i}$ потребує глибокого теоретичного осмислення. На часі - визначення сутності українського патріотизму не стільки за етнічними чи етнокультурними, скільки за ціннісними критеріями. Сьогодні, як ніколи, набувають актуальності та злободенності слова, сказані свого часу В. Липинським: «Бути патріотом - це значить бажати всіма силами своєї душі створення людського, державного і політичного співжиття людей, що житимуть на Українській землі, а не мріяти про втоплення у Дніпрі більшості своїх же власних земляків. Бути патріотом це значить шукати задоволення не в тім, «щоб бути українцем», а в тім, щоб було честю носити ім'я українця. Бути патріотом це значить вимагати гарних і добрих учинків від себе, як від українця, а не ненавидіти інших тому, що вони «не українці». Врешті бути патріотом, це значить, будучи українцем, виховувати в собі громадські, політичні, державотворчі прикмети...» [8]. Тому, саме патріотичне виховання має забезпечувати становлення самодостатнього громадянина-патріота України, готового до виконання своїх громадянських обов'язків.

У трактуванні поняття патріотизму науковці виокремлюють кілька форм його прояву: етнічний, територіальний, державний. Водночас, патріотизм розглядається багатьма дослідниками в різних аспектах: соціально-політичному, історичному, економічному тощо.

Так, В. Скуратівський визначає патріотизм як любов до батьківщини, відповідальність за іiі долю і готовність служити iii інтересам, а в разі потреби самовіддано боронити здобутки свого народу; соціально-політичний i моральний принцип, що в загальній формі виражає вищеназвані почуття та емоційні стани[3]. М. Тофтул називає патріотизмом любов та відданість своїй батьківщині, прагнення своїми діями служити іï інтересам, готовність іти на жертви в ім'я інтересів свого народу. На його думку, патріотизм виявляється в почутті гордості за матеріальні і духовні надбання свого народу, прагненні зберегти самобутність своєї культури, мови, традицій предків[17]. В. Явір тлумачить патріотизм як моральний принцип, суть якого проявляється у любові до Батьківщини, готовності поступитися своїми приватними інтересами на користь п інтересів; як відданість своїй батьківщині, своїй нації. «Під патріотизмом розуміють гордість власною батьківщиною, незалежно від iii рівня розвитку, міжнародного статусу. Патріот пишається досягненнями своєї батьківщини та досягненнями співвітчизників у будь-яких життєвих ситуаціях. Патріотизм означає гордість культурою, мовою батьківщини, бажання зберегти іiі особливості. Передбачає обов'язкову ідентифікацію з нацією, бажання захищати та відстоювати іiі інтереси, досить часто навіть вусупереч раціональним міркуванням» - наголошує вчений [12].

Узагальнюючи різні наукові підходи щодо визначення патріотизму, ми вбачаємо у патріотизмі ціннісне відображення в свідомості людини ставлення до Батьківщини, що обумовлює соціальну активність та цілеспрямовану діяльність задля іiі блага. У ставленні до Батьківщини людина ідентифікується як громадянин, а патріотизм виступає в єдності духовної, громадянської і соціальної активності особистості, соціальної групи, спільноти, що усвідомлюють свій нероздільний зв'язок 3 Вітчизною. Саме у такому розумінні патріотизм як соціокультурна цінність виступає в якості найважливішого компонента формування української нації та важливим чинником забезпечення національної безпеки держави.

Військова практика та результати соціологічних досліджень свідчать, що ставлення української молоді до військової служби неоднозначне. Частина молодих людей не бажає служити у ЗС України та ухиляється від мобілізації. Очевидним $\epsilon$ зменшення конкурсу при вступі у ВВНЗ. Реалії сучасного життя демонструють, що поряд із волонтерством i бажанням допомогти армії, в українському суспільстві мають місце й анти армійські настрої. Як явище суспільної психології і суспільної свідомості, вони відображають тенденції розвитку думок, поглядів, інтересів, емоцій, почуттів, що формуються під впливом низки причин, котрі зумовлюють негативне 


\section{Питання психології}

ставлення молодих людей до служби в ЗС України й армії загалом [15].

3 огляду на вищевикладене, доцільним видається підвищення ролі допризовної військової підготовки. Проте, тривалий час кількість навчального часу у типових навчальних програмах «Захист Вітчизни» для 10-11 класів (рівень стандарт) у закладах середньої освіти обмежувалась 70 академічними годинами. Лише з 2017 року навчальне навантаження збільшилось до 105 академічних годин . Постановою Кабінету Міністрів України № 143 від 26 лютого 2020 p. учні шкіл вивчатимуть замість «Захисту Вітчизни» оновлений предмет «Захист України» [13], мета якого полягає у наданні учням знань та умінь для оборони країни, навчання їх діяти в надзвичайних ситуаціях. Ця дисципліна, як складова допризовної підготовки та військово-патріотичного виховання, спрямована на підготовку юнаків у теоретичному, практичному, фізичному i психологічному плані до майбутньої військової діяльності.

Зауважимо, що раціональний рівень патріотизму неможливий без усвідомлення національних інтересів, які обумовлюють активне ставлення громадян до своєї Батьківщини та їхню патріотичну діяльність. В нинішніх умовах патріотизм в Україні можна визначити як спосіб i форму національної самосвідомості, а патріотичну діяльність - як спосіб реалізації національних інтересів народу.

У новій редакції Концепції національнопатріотичного виховання в системі освіти України, затвердженій наказом $\mathrm{MOH}$ України № 1038 від 29.07.2019 р. вказується, що найбільш актуальними серед виховних напрямів «...виступають громадянськопатріотичне, духовно-моральне, військовопатріотичне виховання як основні складові національно-патріотичного виховання, як стрижневі, основоположні, що відповідають як нагальним вимогам і викликам сучасності, так і закладають підвалини для формування свідомості нинішніх і прийдешніх поколінь, які розглядатимуть розвиток держави як запоруку власного особистісного розвитку, що спирається на ідеї гуманізму, соціального добробуту, демократії, свободи, толерантності, виваженості, відповідальності, здорового способу життя, готовності до змін та до виконання обов'язку із захисту незалежності та територіальної цілісності України» [5].

Відповідно до Концепції, мета національно-патріотичного виховання молоді в Україні має конкретизуватися через систему таких виховних завдань:

- утвердження в свідомості і почуттях особистості патріотичних цінностей, переконань i поваги до культурного та історичного минулого України;

- виховання поваги до Конституції України, законів України, державної символіки;

- підвищення престижу військової служби, а звідси - культивування ставлення до військовослужбовця як до захисника України, героя;

- усвідомлення взаємозв'язку між індивідуальною свободою, правами людини та її патріотичною відповідальністю;

- сприяння набуттю патріотичного досвіду на основі готовності до участі в процесах державотворення, уміння визначати форми та способи своєї участі в життєдіяльності громадянського суспільства, спілкуватися 3 соціальними інститутами, органами влади, спроможності дотримуватись законів та захищати права людини, готовності взяти на себе відповідальність, здатності розв'язувати конфлікти відповідно до демократичних принципів;

- формування толерантного ставлення до інших народів, культур і традицій;

- утвердження гуманістичної моральності як базової основи громадянського суспільства;

- культивування кращих рис української ментальності працелюбності, свободи, справедливості, доброти, чесності, бережного ставлення до природи;

- формування мовленнєвої культури;

- спонукання зростаючої особистості до активної протидії українофобству, аморальності, сепаратизму, шовінізму, фашизму.

$$
\text { Сьогодні залишаються вкрай }
$$
актуальними завдання патріотичного виховання в системі вищої військової освіти формування у курсантів (слухачів, студентів) якостей громадянина-патріота, глибокого почуття любові до України, ії народу; поваги до Конституції України та інших законів; виховання бойових якостей, духовної та психологічної готовності зі зброєю в руках захищати Українську державу; особистої відповідальності за оборону і безпеку України та свідомого виконання вимог військової присяги і статутів ЗС України, наказів Міністерства оборони України, Головнокомандувача Збройних Сил України 


\section{Питання психології}

i начальника Генерального штабу ЗС України.

Дослідники зауважують, що патріотичне виховання у ВВНЗ визначено, попри всі його особливості, режимом роботи закладу вищої освіти такого типу, та є суб'єкт-суб'єктним процесом, ключовою фігурою в якому постає курсант.

Проведення патріотичного виховання серед курсантів та слухачів було зазначено серед основних завдань ВВНЗ у «Положенні про вищі військові навчальні заклади», яке було затверджене наказом Міністра оборони України № 240 від 27 травня 2015 р. [9]. У «Положенні про особливості організації освітнього процесу у вищих військових навчальних закладах Міністерства оборони України та військових навчальних підрозділах вищих навчальних закладів України», затвердженого наказом Міністра оборони України № 346 від 20.07.2015 р., зазначалось, що «виховна робота у ВВН3 (ВНП ВНЗ) $є$ невід'ємною частиною освітнього процесу i включає в себе організаційні, морально-психологічні, педагогічні, інформаційні, культурнопросвітницькі та військово-соціальні заходи, які проводяться 3 метою формування у курсантів (слухачів, студентів) моральнопсихологічних якостей, необхідних для військової служби, готовності виконувати завдання за будь-яких умов бойових дій на фоні високої емоційної напруженості» [10] .

На жаль, у затвердженому наказом Міністерства оборони України № 4 від 09.01.2020 p. «Положенні про особливості організації освітньої діяльності у вищих військових навчальних закладах Міністерства оборони України та військових навчальних підрозділах закладів вищої освіти» не виокремлено розділ виховної роботи, яка $\epsilon$ важливою складовою освітнього процесу у будь-якому університеті [11]. Нинішні світові виховні тенденції та військово-педагогічна практика спираються на гуманістичну особистісноорієнтовану модель виховання майбутніх офіщерів та наукове обгрунтування всіх іiі компонентів, а також встановлення суб'єктсуб'єктних відносин у процесі військового виховання. Суб'єктів, які здійснюють патріотичне виховання особового складу ЗС України слід розглядати на двох рівнях: нарівні українського суспільства та ЗС України. Суб'єктами виховання у ЗС України є: Міністерство оборони України, Генеральний штаб ЗС України та інші органи військового управління, які визначають організацію патріотичного виховання особового складу та його ідеологічну спрямованість на всіх рівнях до військової частини (підрозділу) включно; командири (начальники), офіцери структур по роботі 3 особовим складом та інші посадові особи, які мають підлеглих і відповідають за їх виховання; вищі військові навчальні ВВН3, будинки офіцерів, військові музеї і кімнати бойової слави, бібліотеки, ансамблі пісні i танцю, військово-музичні центри, військові засоби масової інформації та ін.; військові колективи та соціальне середовище загалом. Об'єктами, на які здійснюється виховний вплив шляхом проведення патріотичних заходів у ЗС України, виступають військовослужбовці та працівники ЗС України.

Об'єктом патріотичного виховання у ВВН3 та ВНП ЗВО виступає конкретний курсант (студент, слухач), група, військовий колектив. Абсолютна більшість курсантів та студентів - це молоді люди. Враховуючи, що об'єктом виховання в системі вищої військової освіти $€$ конкретна особистість майбутнього військового інтелігента, то важливо розуміти, що ефективність і дієвість цього процесу зумовлюється i його цілеспрямованим самовдосконаленням самонавчанням, самовихованням, самоосвітою.

Система патріотичного виховання у ВВНЗ та ВНП ЗВО виступає як сукупність закономірно побудованих, динамічно пов'язаних компонентів: мети, завдань, змісту, засобів української етнопедагогіки, умов їх реалізації та взаємодії суб'єктів, які формують патріотизм у дусі природно історичного розвитку української нації на кожному етапі цілеспрямованого, планомірного військово-педагогічного процесу. В системі вищої військової освіти патріотичне виховання $\epsilon$ організованим, планомірним і цілеспрямованим процесом передачі курсантам (студентам, слухачам) національних цінностей і норм культури, вчинків i дії на благо народу і держави, готовності до захисту Вітчизни і спирається на систему національно-патріотичного виховання у ЗС України .

Методика національно-патріотичного виховання в системі військової освіти має свою специфіку: 1) методи виховання майбутніх військовослужбовців забезпечують формування високих морально-правових i бойових якостей, необхідних захиснику Батьківщини; 2) вони спрямовані на формування колективістської 


\section{Питання психології}

психології, згуртування військових колективів, створення здорового моральнопсихологічного клімату, відносин дружби, товариськості, взаємодопомоги; 3) провідне місце належить методам переконання i вправ; 4) методи національно-патріотичного виховання слугують благородним цілям виховання зрілих, всебічно освічених, гармонійно розвинених особистостей; 5) вони грунтуються на гуманізмі, глибокій повазі до особистої гідності воїна, його громадянських прав і свобод.

Зауважимо, що організація процесу національно-патріотичного виховання в системі вищої освіти $\epsilon$ складовою ідеологічної роботи в ЗС України та одним 3 провідних завдань органів по роботі 3 особовим складом 3С України та системи військової освіти і науки. У Концепції ідеологічної роботи у Збройних силах України вказується, що вона $\epsilon$ цілеспрямованою діяльністю органів військового управління, командирів, штабів, органів по роботі з особовим складом усіх рівнів щодо формування у військовому середовищі системи світоглядних ідеалів, цінностей та орієнтирів в інтересах ефективного вирішення завдань оборони України, захисту іiі суверенітету, територіальної цілісності і недоторканності та має цілий спектр завдань. Напрямами ідеологічної роботи визначено військопатріотичне виховання, культурнопросвітницьку роботу, інформаційнопропагандистське забезпечення, захист від негативного інформаційно-психологічного впливу [6].

Ми поділяємо думку Я. Романовського, що зміст національно-патріотичного виховання майбутнього офіцера «...розкривається через вивчення національної історії, культури, народних традицій, звичаїв, обрядів, формування у курсантів ВВНЗ спроможності давати власну оцінку історичним подіям і фактам минулого i сучасного, забезпечення якнайповнішого задоволення національно-культурних інтересів...», а патріотизм «...виступає у вигляді патріотичних якостей, у кожній 3 яких поєднується пізнавальний, емоційний, вольовий, поведінковий компонент: патріотична самосвідомість, почуття патріотичного обов'язку і відповідальності, патріотична мужність, прихильність до національних та загальнолюдських цінностей, почугтя національної гідності та гордості» [14].
Важливу роль у реалізації змісту патріотичного виховання відіграє як аудиторна так i поза аудиторна робота. Основними іiі формами в системі військової освіти $\epsilon$ проведення тематичних лекцій, бесід, диспутів, вікторин, вечорів та творчих змагань 3 питань історії України та іiі Збройних Сил; тематичних вечорів 3 нагоди пам'ятних дат 3 історико-патріотичної тематики; святкування державних свят (3 нагоди Дня проголошення незалежності України, Для Перемоги у Другій світовій війні, Дня Збройних Сил України, Дня народження Т.Г. Шевченка, Дня вшанування учасників бойових дій, річниці звільнення території України від німецько-фашистських загарбників тощо); літературно-художніх та музичних вечорів, читацьких конференцій 3 обговоренням художньої та публіцистичної літератури; оглядів матеріалів періодичних видань щодо питань військової справи; місячників військово-патріотичного виховання та оборонно-масової роботи; кінолекторіїв із військово-патріотичної та історичної тематики.

Важливими формами патріотичного виховання в системі військової освіти $\epsilon$ організація творчих зустрічей курсантів 3 ветеранами Збройних Сил, творчими колективами, працівниками культури i мистецтва, творчої інтелігенції; відвідування військово-історичних та історичних музеїв, місць бойової слави, меморіалів та пам'ятників борцям за свободу та незалежність України; військових ритуалів (урочисте прийняття Військової присяги, вручення особистої зброї тощо); участі в історико-патріотичних заходах, які проводяться місцевими органами влади, громадськими організаціями та рухами, музеями, закладами культури; оглядівконкурсів художньої самодіяльності.

Важливою складовою і пріоритетними напрямами патріотичної роботи в системі вищої військової освіти є системна робота щодо збереження і культивування у кожному колективі національних традицій і звичаїв; виховання в курсантів (студентів, слухачів) почуття гордості за свою країну та Збройні сили. 3 огляду на це, пріоритетним напрямом державної політики у сфері патріотичного виховання, вважають експерти, має стати робота з формування національної свідомості та гідності, вивчення справжньої, не фальсифікованої історії України, знання славних i водночас трагічних сторінок визвольної боротьби іiі народу за власну державність. 


\section{Питання психології}

Маємо вказати також i за зміну модифікацій педагогічного інструментарію та вдосконалення форм i методів поза аудиторної діяльності у ВВНЗ та ВНП ЗВО на початку XXI століття у порівнянні 3 минулим століттям. Зокрема, щороку активніше використовуються інформаційнокомунікаційні технології як у освітній, так і у виховній роботі.

Однак, як свідчить реальна практика патріотичного виховання у ВВНЗ та ВНП ЗВО, об'єкт виховання нині відчуває гострий дефіцит демократичних форм i методів виховного впливу. 3 одного боку, - це наслідок тривалого існування адміністративно-авторитарного мислення i стилю поведінки, а 3 іншого, - результат невміння жити і працювати в нових умовах, адекватно реагувати на нові виклики i використовувати нові можливості.

Отже, основними педагогічними умовами забезпечення ефективності системи національно-патріотичного виховання в системі військової освіти, на думку фахівців, має стати цілеспрямоване вдосконалення організаційно-методичного забезпечення процесу військово-патріотичного виховання, розроблення, видання та використання у ньому сучасних науково-методичних матеріалів для військових вихователів, комплексне використання сучасних методів, методик i технологій впливу на інтелектуальну, емоційно - вольову та мотиваційну сфери психіки особистості військовослужбовця та психологію військового колективу тощо [2].

Ефективність патріотичного виховання залежить переважно від рівня педагогічної майстерності, людяності, моральної привабливості, інтелектуального багатства суб'єктів військово-патріотичного виховання. Патріотичну спрямованість освітнього процесу забезпечують, у першу чергу, керівні та науково-педагогічні працівники ВВНЗ, які мають поряд 3 високими військово-професійними якостями володіти широким світоглядом, науковими поглядами та задовольняти сучасні суспільні потреби у підготовці патріотично налаштованого українського офіцера. Тому на виховну роботу у ВВНЗ доцільно призначати офіцерів, які особистим прикладом підтверджуватимуть власні переконання, які здібні аналітично мислити, чути й переконувати людей. Це мають бути фахівці з високим рівнем теоретичної i практичної підготовки, носії традицій i культурних цінностей українського народу, спроможні професійно вирішувати сучасні завдання військової служби і на цій основі навчати i виховувати відданих інтересам Української держави воїнів.

В епоху інформаційного суспільства не можна недооцінювати ролі ЗМІ у справі національно-патріотичного виховання як українського суспільства в цілому, так i майбутніх офіцерів зокрема. Незважаючи на засилля в Україні інформації різного гатунку (теле-, радіопередачі, газети, журнали, книги, брошури, навчальна література, відео- та аудіо продукція, кінофільми тощо) в українському суспільстві в цілому та у Збройних Силах і в системі військової освіти Україні зокрема відчувається недостатність інформації патріотичного спрямування. На жаль, доволі рідкими явищами в системі виховної роботи більшості закладів вищої освіти i ВВНЗ $є$ українські вистави, кінофільми, друкована продукція, що за своїм змістом спрямовані на підняття іміджу України, іiі Збройних Сил, на піднесення патріотичного духу військовослужбовців, молоді України.

Інформаційний контент вітчизняних 3МI не завжди сприяє формуванню високої патріотичної свідомості, моральному та позитивному ставленню населення до армії. Так, мають місце неповага, невігластво щодо наших національних ідеалів i святинь, брутальні висловлювання, безапеляційні оцінки, безвідповідальні трактування української минувшого та сьогодення, нехтування героїзмом минулих поколінь та сучасників. За нинішніх умов очевидною $\epsilon$ безвідповідальність i безкарність тих представників ЗМI, хто елементарно паплюжить те, що є святим для свідомого українця.

Проте, маємо відзначити, що останнім часом відбулись певні зрушення у напрямі державного впливу на патріотичне виховання українського суспільства. Але, на жаль, невеликий тираж друкованої продукції Міністерства інформаційної політики України з безкоштовним розповсюдженнями у 2018-2019 pр. по закладам освіти i бібліотекам України, та незначна кількість патріотичних, україноцентричних робіт в онлайн бібліотеці на офіційному сайті цього відомства не можуть задовольнити суспільних запитів в отриманні патріотичного контенту.

Вважаємо, що незаперечний вплив на свідомість українців має вихід в прокат патріотичних кінофільмів «Заборонений», «Додому», «Захар Беркут», «Ціна правди», 


\section{Питання психології}

«Вулкан», «Сквот32», «Крути 1918», «Чорний ворон» (2019), «Нескорений» (2000) «Залізна сотня» (2004), «Червоний» (2017), «Той, хто пройшов крізь вогонь» (2012). Але вони лише частково заповнюють прогалину у патріотичному вихованні українських громадян, яка утворилася за роки незалежності. Українському суспільству сьогодні вкрай потрібні фільми військовопатріотичного спрямування на зразок документальних та кінофільмів «Добровольці Божої чоти», «Рейд. Сила нескорених» (2015), «Кіборги», «Одесити на Донбасі», «Війна химер», «Іній» (2017), «Черкаси», «Вдивляючись в темряву», «На своій землі〉 (2019), в яких висвітлено роль воїнів ЗС України у війні на Сході України, значення патріотизму громадян для збереження держави.

Ми поділяємо думку експертів, що національними інтересами України має бути розвиток інтелектуального потенціалу українського народу, формування національно-культурної ідентичності, патріотичного світогляду, збереження та розвиток духовно-моральних цінностей українців, зміцнення фізичного здоров'я нації. А серед основних напрямів державної політики у сфері національної безпеки формування та розвиток національнокультурної ідентичності, патріотичного світогляду Українського народу, збереження його духовно-моральних цінностей; взаємодія органів державної влади та органів місцевого самоврядування у сфері патріотичного виховання, забезпечення широкої громадської підтримки цих процесів, підвищення ролі сім’ї і волонтерських організацій. Одним із основних завдань воєнної політики України у найближчий час i в середньостроковій перспективі має стати військово-патріотичне виховання особового складу Збройних Сил України та інших військових формувань, підняття престижу військової служби, утвердження духовності, моральності, шанобливого ставлення до національних надбань українського народу, наслідування найкращих прикладів мужності та звитяги борців за свободу i незалежність нашої держави [1].
Як слушно вказує С. Сьомій, «національно-патріотичне виховання молоді, як невід'ємна складова системи забезпечення національної безпеки України, - це комплексна системна i цілеспрямована діяльність державної влади, місцевого самоврядування, громадськості, сім'ї, освітніх закладів та інших соціальних інститутів, спрямована на формування у молодого покоління високої патріотичної свідомості, почуття вірності й любові до Батьківщини, постійної готовності до виконання свого обов'язку із захисту національних інтересів» [16].

Висновок та перспективи подальших досліджень. Таким чином, в умовах реформування вищої освіти та ЗС України для підтримання бойового потенціалу ЗС України та забезпечення безпеки нашої держави, необхідна відповідна фахова підготовка особового складу та формування патріотично налаштованого офіцерського корпусу, здатного вирішувати спеціальні завдання. Це забезпечується організацією освітнього процесу у ВВНЗ та ВНП ЗВО на основі компетентністно орієнтованої моделі фахової підготовки та україноцентричної системи національно-патріотичного виховання.

Формуванню нової генерації українських офіцерів, які розглядатимуть розвиток держави як запоруку власного особистісного й професійного розвитку, виявлятимуть готовність до змін та до виконання обов'язку із захисту незалежності та територіальної цілісності України мають слугувати науково - обгрунтована державна стратегія формування патріотизму та виважена, послідовна і комплексна реалізація запланованих заходів у системі військової освіти. Ефективність патріотичного виховання в ВВНЗ та ВНП ЗВО України $\epsilon$ тим морально - ідеологічним стрижнем, на якому грунтується національна безпека держави та консолідуються духовні сили військовослужбовців навколо національної ідеї, вірності та відданості Батьківщині, соціальної відповідальності та морального обов'язку.

\section{Список використаних джерел}

1. Аналітична записка НІСД. Патріотичне виховання молоді як невід'ємна складова системи забезпечення національної безпеки України. с. 15. [Електронний ресурс] - Режим доступу: https://niss.gov.ua/doslidzhennya/nacionalna-bezpeka/patriotichne-vikhovannya-molodi-yak-nevidemnaskladova-sistemi 


\section{Питання психології}

2. Баранівський В.Ф., Тарасенко О.В. Система військово-патріотичного виховання курсантів вищого військового навчального закладу // Військова освіта. Збірник наукових праць Національного університету оборони України імені Івана Черняхівського - 2015 - № (31)-С. 25-30.

3. Гринченко Б.Д. Діалог про українську національну справу. / Б. Д. Гринченко, М. П. Драгоманов; упоряд. А. Жуковський. - К.: б.в., 1994. - 286 с.

4. Зонь В.В. Військово-патріотичне та вольове виховання як важлива складова формування особистості військовослужбовця / В.В. Зонь // Народна армія. - 2005. - 12 квітня. - С. 7.

5. Концепція національно-патріотичного виховання в системі освіти України, затверджена наказом МОН України № 1038 від 29.07.2019 р. [Електронний ресурс]. - Режим доступу: https://mon.gov.ua/storage/app/uploads/public/5d5/279/7ca/5d52797ca746c359374718.pdf

6. Концепція ідеологічної роботи у Збройних Силах України, затверджена наказом Міністра оборони України від 5 лютого 2013 року № 78. [Електронний ресурс]. - Режим доступу: https://zakon.rada.gov.ua/rada/show/v1453729-13\#Text.

7. Крилов С.А. В «зірницю» вже давно не грають / С.А. Крилов // Оборонний вісник. - 2014.-№ 10.-C 30-32.

8. Лист В. Липинського до Б. Шемета. Писаний у Райхенау 12.12.1925p. // Мала енциклопедія етнодержавознавства. НАНУ. Ін-т держави і права ім. В.М. Корецького; редкол.: Римаренко Ю.І. (відп. ред.) та ін. - К: Довіра. Генеза. - 1996. - С. 745-746.

9. Наказ Міністерства оборони України від 27.05.2015 р. №240. Про затвердження Положення про вищі військові навчальні заклади. [Електронний ресурс]. - Режим доступу: http://search.ligazakon.ua/1_doc2.nsf/link1/RE27151.html.

10. Наказ Міністерства оборони України від 20.07.2015 р. № 346. Про затвердження Положення про особливості організації освітньої діяльності у вищих військових навчальних закладах Міністерства оборони України та військових навчальних підрозділах закладів вищої освіти України.[Електронний pecypc]. - Режим доступу: https://zakon.rada.gov.ua/laws/show/z1126-15\#Text

11. Наказ Міністерства оборони України від 09.01.2020 №4. Про затвердження Положення про особливості організації освітньої діяльності у вищих військових навчальних закладах Міністерства оборони України та військових навчальних підрозділах закладів вищої освіти України. [Електронний pecypc]. - Режим доступу: https://zakon.rada.gov.ua/laws/show/z0250-20\#Text

12. Політична енциклопедія. Редкол.: Ю. Левенець (голова). Ю. Шаповал (засг. голови) та ін. К.: Парламентське видавництво, 2011. - С. 546.

13. Постанова Кабінету Міністрів України від 20 лютого 2020 року № 143. Про внесення змін до деяких постанов Кабінету Міністрів України. [Електронний ресурс]. - Режим доступу: https://zakon.rada.gov.ua/laws/show/143-2020-\%D0\%BF\#Text

14. Романовський Я. Я. Історичні витоки формування патріотизму особистості у збройних силах України / Я.Я. Романовський // Держава та армія: [збірник наукових праць] / відповідальний редактор Л.Є. Дещинський. - Львів: Видавництво Національного університету «Львівська політехніка». 2008. № 634.- С. 180-186.

15. Староконь Є. Г. Психологічні аспекти виховної діяльності та спілкування офіцера / Є. Г. Староконь. - Житомир : ЖВIPЕ, 1999. - 304 с.

16. Сьомій С.В. Проблеми патріотичного виховання в Україні: теоретико- методологічний та правовий аспект // Стратегічні пріоритети. 2016 - № 2 (39). - С. 96-105. 295-296.

17. Тофтул М.Г. Сучасний словник з етики. - Житомир: Вид-во ЖДУ ім. І. Франка. 2014. - с.

\section{References}

1. Analitychna zapyska NISD. Patriotychne vykhovannya molodi yak nevidyemna skladova systemy zabezpechennya natsionalnoyi bezpeky Ukrainy [Patriotic education of youth as an integral part of the national security system of Ukraine]. s. 15.

2. Baranivskyi, V., Tarasenko, O. (2015) Systema viyskovo-patriotychnoho vykhovannya kursantiv vyshchoho viyskovoho navchalnoho zakladu [System of military-patriotic education of cadets of higher military educational institution]. Viyskova osvita. Zbirnyk naukovykh prats. Natsionalniy universytet oborony Ukrayini imeni Ivana Chernyakhivskoho № (31) S. 25-30.

3. Grinchenko, B. (1994) Dialogy pro ukrainsku nacionalnu spravu [Dialogue on the Ukrainian national cause]. K.: b.v., 286 s. (in Ukrainian).

4. Zon, V. (2005) Viyskovo-patriotychne ta volove vykhovannya yak vazhlyva skladova formuvannya osobystosti viyskovosluzhbovtsya [Military-patriotic and volitional education as an important component of the formation of a serviceman's personality]. Narodna armiya. S. 7. (in Ukrainian).

5. Nakaz MON Ukrainy. Kontseptsiya natsionalno-patriotychnoho vykhovannya $\mathrm{v}$ systemi osvity Ukrayiny [The concept of national-patriotic education in the education system of Ukraine, approved by the order of the Ministry of Education and Science of Ukraine] 29.07.2019 r. № 1038. (in Ukrainian). 


\section{Питання психології}

6. Nakaz Ministerstva oborony Ukrainy. Kontseptsiya ideolohichnoyi roboty u Zbroynykh Sylakh Ukrainy [Order of the Ministry of Defense of Ukraine. The concept of ideological work in the Armed Forces of Ukraine]. 5.02. 2013 r. № 78. (in Ukrainian).

7. Krylov, S. (2014) V «zirnytsyu» vzhe davno ne hrayut [The «star» has not been played for a long time]. Oboronnyy visnyk. № 10. S 30-32. (in Ukrainian).

8. Rymarenko, YU. (1996) Lyst V. Lypynskoho, do B.Shemeta. Pysanyy u Raykhenau 12.12.1925r. [Letter of V. Lypynsky to B. Shemet. Written in Reichenau on December 12, 1925]. Mala entsyklopediya etnoderzhavoznavstva. K: Dovira. Geneza. S. 745-746. (in Ukrainian).

9. Nakaz Ministerstva oborony Ukrainy. Pro zatverdzhennya Polozhennya pro vyshchi viyskovi navchalni zaklady [Order of the Ministry of Defense of Ukraine. On approval of the Regulations on higher military educational institutions]. 27.05.2015 r. №240. (in Ukrainian).

10.Nakaz Ministerstva oborony Ukrainy. Pro zatverdzhennya Polozhennya pro osoblyvosti orhanizatsiyi osvitnoyi diyalnosti u vyshchykh viyskovykh navchalnykh zakladakh Ministerstva oborony Ukrainy ta viyskovykh navchalnykh pidrozdilakh zakladiv vyshchoyi osvity Ukrainy [Order of the Ministry of Defense of Ukraine. On approval of the Regulations on the peculiarities of the organization of educational activities in higher military educational institutions of the Ministry of Defense of Ukraine and military educational units of higher education institutions of Ukraine]. 20.07.2015 r. № 346. (in Ukrainian).

11.Nakaz Ministerstva oborony Ukrainy. Pro zatverdzhennya Polozhennya pro osoblyvosti orhanizatsiyi osvitnoyi diyalnosti u vyshchykh viyskovykh navchalnykh zakladakh Ministerstva oborony Ukrainy ta viyskovykh navchalnykh pidrozdilakh zakladiv vyshchoyi osvity Ukrainy [Order of the Ministry of Defense of Ukraine. About the statement of the Situation on features of the organization of educational activity in the higher military educational institutions of the Ministry of Defense of Ukraine and military educational divisions of the higher education institutions of Ukraine]. 09.01.2020 № 4. (in Ukrainian).

12.Levenets, YU., Shapoval, YU. (2011) Politychna entsyklopediya [Political encyclopedia]. K.: Parlamentske vydavnytstvo. S. 546. (in Ukrainian).

13.Postanova Kabinetu Ministriv Ukrainy. Pro vnesennya zmin do deyakykh postanov Kabinetu Ministriv Ukrainy.[Resolution of the Cabinet of Ministers of Ukraine. On amendments to some resolutions of the Cabinet of Ministers of Ukraine] 20 .02. 2020 r. № 143. (in Ukrainian).

14.Romanovskyi, YA. (2008) Istorychni vytoky formuvannya patriotyzmu osobystosti u zbroynykh sylakh Ukrainy [Historical origins of the formation of patriotism of the individual in the armed forces of Ukraine]. Derzhava ta armiya: zbirnyk naukovykh prats. Lviv: Natsionalniy universytet «Lvivska politekhnika». № 634.- S. 180-186.

15.Starokon, YE. (1999) Psykholohichni aspekty vykhovnoyi diyalnosti ta spilkuvannya ofitsera [Psychological aspects of educational activity and communication of an officer]. Zhytomyr : ZHVIRE, $304 \mathrm{~s}$. (in Ukrainian).

16.Somiy, S. (2016) Problemy patriotychnoho vykhovannya v Ukraini: teoretyko- metodolohichnyy ta pravovyy aspekt [Problems of patriotic education in Ukraine: theoretical, methodological and legal aspect]. Stratehichni prioritety. № 2 (39). - S. 96-105.

17.Toftul, M. (2014) Suchasnyy slovnyk z etyky. [Modern dictionary of ethics] Zhytomyr: ZHDU im. I. Franka. S. 295-296. (in Ukrainian).

\section{Резюме}

Чайковский A. С. доктор исторических наук, профессор, Центр военно-стратегических исследований Начиональный университет обороны Украины Поздымев С. А. кандидат психологических наук, Национальный университет обороны Украины https://orcid.org/0000-0001-7225-709x

Мацько А. И. кандидат военных наук, профессор, Национальный университет обороны Украины https://orcid.org/0000-0003-3415-3358

\section{ПАТРИОТИЧЕСКОЕ ВОСПИТАНИЯ В СИСТЕМЕ ВЫСШЕГО ВОЕННОГО ОБРАЗОВАНИЯ КАК СОСТАВЛЯЮЩАЯ ОБЕСПЕЧЕНИЯ НАЦИОНАЛЬНОЙ БЕЗОПАСНОСТИ УКРАИНЫ}

В статье рассмотрена роль и место патриотического воспитания в системе обеспечения национальной безопасности Украины. Проанализированы различные научные подходы к определению понятия патриотизма. Обнаружены концептуальные основы, составляющие, направления и проблемы патриотического воспитания в национальной системе высшего военного образования, раскрыты его влияние на эффективность обеспечения национальной безопасности Украины. Определены субъекты и объекты патриотического воспитания в Вооруженных Силах Украины.

Ключевые слова: патриотическое воспитание; высшее военное учебное заведение; молодежь; курсант; военнослужащчй; Вооруженные Силь Украины. 


\section{Питання психології}

Summary

Tchaikovsky A. doctor of historical sciences, Professor, Center for Military and Strategic Studies National

Defence University of Ukraine named after Ivan Chernyahovskyi

Pozdyshev S. candidate of psychological sciences, National

Defence University of Ukraine named after Ivan Chernyahovskyi

Matsko O. candidate of military sciences, Professor National

Defence University of Ukraine named after Ivan Chernyahovskyi

PATRIOTIC EDUCATION IN THE SYSTEM OF HIGHER MILITARY EDUCATION AS A COMPONENT OF NATIONAL SUPPORT SECURITY OF UKRAINE

Introduction. At the current stage of development of Ukrainian society, when the country in extreme conditions demonstrates signs of a systemic crisis of all spheres of public and state activity, the problem of ensuring the national security of Ukraine becomes relevant. This is due to both the hybrid aggression against Ukraine by the Russian Federation and the domestic political problems of the national establishment, which have revealed a number of systemic problems in ensuring national security.

Purpose. The purpose of the article is to analyze the conceptual principles, components, directions and problems of patriotic education in the national system of higher military education and to reveal its impact on the effectiveness of national security of Ukraine.

Methods. To solve the goal, general theoretical methods were used: analysis, synthesis of provisions contained in the pedagogical, psychological and relevant literature on the problem studied, comparison of generalizations, interpretation and systematization of theoretical and empirical research.

Originality. Summarizing the various scientific approaches to the definition of patriotism, we see in patriotism a valuable reflection in the human mind attitude to the Motherland, which determines social activity and purposeful activity for its benefit. In relation to the Motherland, a person is identified as a citizen, and patriotism is in the unity of spiritual, civic and social activity of the individual, social group, community, aware of their inseparable connection with the Fatherland. It is in this sense that patriotism as a socio-cultural value acts as the most important component of the formation of the Ukrainian nation and an important factor in ensuring the national security of the state.

The national interests of Ukraine should be the development of the intellectual potential of the Ukrainian people, the formation of national and cultural identity, patriotic worldview, preservation and development of spiritual and moral values of Ukrainians, strengthening the physical health of the nation. And among the main directions of state policy in the field of national security - the formation and development of national and cultural identity, patriotic worldview of the Ukrainian people, the preservation of its spiritual and moral values; interaction of state authorities and local governments in the field of patriotic education, providing broad public support for these processes, increasing the role of family and volunteer organizations. One of the main tasks of Ukraine's military policy in the near and medium term should be military-patriotic education of personnel of the Armed Forces of Ukraine and other military formations, raising the prestige of military service, strengthening spirituality, morality, respect for the national heritage of the Ukrainian people. examples of courage and victory of fighters for freedom and independence of our state.

Conclusion. The formation of a new generation of Ukrainian officers who will consider the development of the state as a guarantee of personal and professional development, will show readiness for change and to fulfill the duty to protect the independence and territorial integrity of Ukraine should serve a scientifically sound state strategy of patriotism and balanced, consistent and comprehensive implementation of planned activities in the military education system. The effectiveness of patriotic education in a higher military educational institution of Ukraine is the moral and ideological core on which the national security of the state is based and the spiritual strength of servicemen is consolidated around the national idea, loyalty and devotion to the Motherland, social responsibility and moral duty.

Key words: patriotic education; higher military educational institution; young; cadet; serviceman; Armed Forces of Ukraine.

Автори заявляють про відсутність конфлікту інтересів.

Recelved/Поступила: 27.01. 21. 